\title{
TINJAUAN DESKRIPTIF: KARAKTERISTIK FAKTOR-FAKTOR HEALTH SEEKING BEHAVIOR PADA PASIEN DISORDER OF SEX DEVELOPMENT
}

\author{
Fitri Mareta Elzandri ${ }^{1}$, Bintang Arroyantri Prananjaya ${ }^{2}$, Ziske Maritska $^{3}$, Abdullah \\ Sahab $^{4}$, Safyudin ${ }^{4}$, MA Husnil Farouk ${ }^{5}$ \\ Program Studi Pendidikan Dokter, Fakultas Kedokteran, Universitas Sriwijaya ${ }^{1}$ \\ Bagian Ilmu Kesehatan Jiwa, Fakultas Kedokteran, Universitas Sriwijaya ${ }^{2,4}$ \\ Bagian Biologi Kedokteran, Fakultas Kedokteran, Universitas Sriwijaya ${ }^{3}$ \\ Bagian Biokimia Kedokteran, Fakultas Kedokteran, Universitas Sriwijaya ${ }^{4}$ \\ Bagian IKM-IKK, Fakultas Kedkteran, Universitas Sriwijaya ${ }^{5}$ \\ fitri.mareta.el88@gmail.com¹, bintangarroyantri@gmail.com²
}

\begin{abstract}
The incidence of Disorder of Sex Development (DSD) 1:4,500-5,500. Even though the incidence of DSD is still low, according to research, many patients are diagnosed with DSD when they are $>2$ years old or during adults. There are patients who experienced late diagnosis caused by the lack of Health Seeking Behavior. This study aim to identify internal and external factors of DSD patients' Health Seeking Behavior at Dr. RSUP Mohammad Hoesin Palembang in 2013-2017. This study is a descriptive study with a cross sectional approach using primary and secondary data which was conducted in January-February 2018. Samples were taken using the total sampling method from all medical record data that met the inclusion criteria. From 120 patient data, 61 samples were obtained as respondent.of DSD patients at Dr. Mohammad Hoesin Palembang in 2013-2017. Patients were diagnosed mostly at age $>6$ years old $-\geq 12$ years old. 54 male patients were mostly diagnosed $(88.5 \%)$. The parents of patients who deliver their children are mostly aged 26-35 years for the age of the mother (52.5\%) and 36-45 years for the age of the father (39.3\%). The last education of parents of DSD patients graduated from high school (78.7\%). The economic status of the parents of DSD patients who came to RSMH were mostly from the upper class (50.8\%) and most patients came from Palembang (23\%). There are still a lot of DSD patients in RSUP Dr. Mohammad Hoesin Palembang categorised as late diagnose judging from the Health Seeking Behavior Factors.
\end{abstract}

Keyword $\quad$ : Disorder Of Sex Development, Ambigous Genitalia, Health Seeking Behavior

\begin{abstract}
ABSTRAK
Angka kejadian Disorder of Sex Development (DSD) 1:4, 500-5.500. Walalupun angka kejadian DSD masih rendah namun menurut penelitian banyak pasien terdiagnosis DSD ketika umur $>2$ tahun bahkan ada yang terdiagnosis ketika dewasa. Terdapat pasien yang mengalami late diagnose disebabkan oleh kurangnya Health Seeking Behavior. Penelitian ini bertujuan untuk mengidentifikasi faktor internal dan eksternal Health Seeking Behavior pasien DSD di RSUP Dr. Mohammad Hoesin Palembang pada tahun 2013-2017. Penelitian ini merupakan penelitian deskriptif dengan pendekatan cross sectional menggunakan data primer dan sekunder yang dilakukan pada bulan Agustus 2018-Januari 2019. Sampel diambil dengan menggunakan metode total sampling dari seluruh data rekam medik yang memenuhi kriteria inklusi. Dari 120 data pasien yang diperoleh, didapatkan 61 sampel pasien DSD di RSUP Dr. Mohammad Hoesin Palembang pada tahun 2013-2017. Pasien terdiagnosis paling banyak saat umur $>6$ - $\geq 12$ tahun sebanyak 22 pasien $(36,1 \%)$. Pasien dengan jenis kelamin laki-laki lebih banyak yaitu ditemukan 54 pasien $(88,5 \%)$. Orang tua pasien yang mengantar anaknya paling banyak berumur 26 35 tahun untuk umur Ibu (52,5\%) dan 36-45 tahun untuk umur Ayah (39,3\%). Pendidikan terakhir orang tua pasien DSD merupakan tamat SMA $(78,7 \%)$. Status ekonomi orang tua pasien DSD yang datang ke RSMH paling banyak ditemukan golongan kelas atas $(50,8 \%)$ dan pasien terbanyak berasal dari Palembang (23\%). Pasien DSD di RSUP Dr. Mohammad Hoesin Palembang masih banyak tergolong late diagnose ditinjau dari beberapa faktor Health Seeking Behavior.
\end{abstract}

Kata Kunci $\quad$ :Disorder Of Sex Development, Ambigu Genitalia, Health Seeking Behavior 


\section{PENDAHULUAN}

Pada setiap kelahiran, pemeriksaan jenis kelamin merupakan salah satu tindakan yang selalu dilakukan oleh para penolong persalinan. Ketika ditemukan kelainan alat kelamin seringkali menimbulkan keraguan dan kerancuan penentuan jenis kelamin pada bayi baru lahir. Bayi baru lahir dengan keadaan genitalia ambigu seringkali dideskripsikan sebagai keadaan emergensi endokrin. Kondisi ini secara medis disebut dengan istilah Disorder of Sexual Development (DSD) (Hughes, 2008).

Disorder of Sexual Development (DSD) adalah kondisi kelainan bawaan yang terjadi pada kromosom, gonad, atau organ reproduksi eksternal (Berglund et al., 2016). Sebelum istilah DSD ada, The European Society for Paediatric Endocrinology (ESPE) and the Lawson Wilkins Pediatric Endocrine Society (LWPES) menyatakan dengan istilah intersex disorder, pseudohermaphroditism, herma-phroditism, dan sex reversal. Sejak konsensus Chicago 2006 istilah DSD baru digunakan (Hughes, 2008).

Di Indonesia belum ada data untuk kejadian DSD, namun di Semarang pada tahun 1991 berhasil mengidentifikasi jumlah penderita yang terdaftar pada laboratorium Sitogenetika Pusat Riset Biomedik FK Undip Semarang untuk pemeriksaan kromosom (sebagai penentu jenis kelamin) $>400$ orang. Sebagian kasus DSD yang terdaftar di Semarang memeriksakan diri saat anak sudah berumur diatas 2 tahun bahkan sudah beranjak dewasa dengan pengasuhan gender yang tidak sesuai, sehingga keadaan ini sangat memprihatinkan di Indonesia (Purwanti, 2016).

Meskipun angka kejadian DSD yang tercatat masih rendah, namun terdapat dampak yang cukup besar bagi orang tua yang memiliki anak dengan DSD. Menurut penelitian tersebut $62,7 \%$ orang tua mengalami depresi. Dampak psikologis pada pasien DSD dibagi menjadi tiga, yaitu: gangguan psikoseksual, gangguan fungsi psikososial di keluarga, sekolah atau di lingkungan kerja, serta gangguan kognitif dan intelektual. Gangguan psikoseksual dipengaruhi oleh 4 aspek, yaitu identitas seksual (sexual identity), identitas gender (gender identity, orientasi sexual (sexual orientation), dan preferensi seksual (sexual behavior) (Suorsa, 2015). Saat ini pemahaman tentang faktor-faktor yang dapat menyebabkan DSD masih kurang. Gangguan tersebut cenderung disebabkan oleh faktor genetik, hormonal, dan lingkungan selama masa perkembangan prenatal dan postnatal (Garcia-Acero et al., 2020).

Tanggapan atau upaya individu dalam menyikapi masalah kesehatannya berbedabeda. Antara lain tidak melakukan upaya apapun, melakukan upaya penyembuhan sendiri tanpa menggunakan obat-obatan, melakukan upaya pengobatan sendiri dengan menggunakan obat-obatan baik modern maupun tradisional/ herbal, dan mengupayakan penyembuhan dengan melakukan rujukan atau berkonsultasi dengan tenaga ahli atau kondisi ini bisa disebut sebagai Health Seeking Behavior (Widayati, 2012). Health Seeking Behavior adalah perilaku seseorang untuk meminta pertolongan pengobatan kepada tenaga kesehatan profesional (Ybarra, 2006).

Untuk penanganan semua pasien dengan DSD memerlukan tim multidisiplin dari tenaga kesehatan profesional, karena masalah yang terkait dengan DSD bersifat multidimensi dan dengan demikian memerlukan kerjasama dari sejumlah disiplin untuk memberikan diagnosis, pengobatan, dan dukungan yang efektif. Tim manajemen yang ideal mencakup subspesialis pediatrik di bidang endokrinologi, bedah dan/atau urologi, psikologi atau psikiatri, ginekologi, genetika, neonatologi, 
dan jika tersedia, pekerja sosial dan perawat, dan lainnya. Tim multidisiplin ini memainkan peran penting dalam penyediaan perawatan dan bertujuan untuk kesejah-teraan fisik dan psikologis individu dengan DSD dan keluarga mereka (Garcia-Acero et al., 2020).

Dari data yang ditemukan di Semarang banyak pasien DSD memeriksakan diri ketika berumur diatas 2 tahun bahkan pada umur remaja dengan pengasuhan gender yang tidak sesuai. Penelitian mengenai Health Seeking Behavior pada pasien DSD di RSMH juga belum banyak dilakukan, sehingga penelitian tentang faktor yang memengaruhi Health Seeking Behavior pada pasien DSD penting untuk dilakukan supaya pasien DSD cepat terdiagnosis. Tujuan dari penelitian ini yaitu untuk mengetahui gambaran faktor-faktor yang memengaruhi perilaku mencari pertolongan pengobatan (Health Seeking Behavior) pada pasien Disorder of Sex Development (DSD) di RSUP Dr. Mohammad Hoesin Palembang.

\section{METODE}

Penelitian ini deskriptif observasional dengan pendekatan cross sectional. Penelitian dilakukan pada bulan Agustus 2018-Januari 2019. Populasi terjangkau pada penelitian ini adalah semua pasien DSD yang berobat maupun rawat inap di RSUP Dr. Mohammad Hoesin Palembang pada tahun 2013-2017. Pada penelitian ini ditambahkan kriteria drop out, yaitu pasien yang data rekam medisnya tidak lengkap. Pada penghitungan besar sampel ditambahkan 10\% dari besar sampel. Jadi, besar sampel minimal pada penelitian ini sebanyak 42. Teknik pengambilan sampel penelitian ini diambil dengan total sampling,. Pada penelitian ini berhasil dikumpulkan 61 subjek penelitian.

Kriteria inklusi penelitian ini yaitu Semua pasien di RSUP Dr. Mohammad Hoesin yang terdiagnosis Disorder of Sexual Development maupun dengan istilah Intersex
Disorder, Pseudohermaphroditism, Her maphroditism, dan Sex Reversal atau semua pasien yang dinyatakan termasuk ke dalam klasifikasi DSD seperti Turner Syndrome, Klinefelter Syndrome, Ovotesticular DSD dan Mixed Gonadal Dsygenesis (Lee et al., 2006). Kriteria eksklusi penelitian ini yaitu Pasien yang data rekam medisnya tidak tercatat kontak yang dapat dihubungi dan pasien dan atau orang tua pasien yang menolak berpartisipasi pada saat penelitian.

Data dianalisis secara univariat menggunakan program statistik IBM SPSS Statistik 20 dan hasil penelitian disajikan dalam bentuk tabel yang dijelaskan dengan narasi.

HASIL

Tabel 1. Karakterisitik Umur dan Jenis Kelamin Pasien DSD di RSUP Dr. Mohammad Hoesin Palembang $(\mathbf{n}=61)$

\begin{tabular}{|c|c|c|}
\hline Karakteristik Umur & $\mathbf{n}$ & $\%$ \\
\hline$\leq 1$ bulan $($ neonates $)$ & 2 & 3,3 \\
\hline$>1$ bulan $-\leq 1$ tahun (early-infancy) & 2 & 3,3 \\
\hline$>1$ tahun $-\leq 2$ tahun (late-infancy) & 3 & 4,9 \\
\hline$>2$ tahun $-\leq 6$ tahun (early-childhood) & 19 & 31,1 \\
\hline$>6$ tahun $-\leq 12$ tahun (late-childhood) & 22 & 36,1 \\
\hline$>12$ tahun $-\leq 15$ tahun (prepubertal) & 6 & 9,8 \\
\hline$>15$ tahun $-\leq 18$ tahun (adolescenes) & 2 & 3,3 \\
\hline$>18$ tahun (adults) & 5 & 8,2 \\
\hline Total & 61 & 100 \\
\hline Jenis Kelamin & $\mathbf{n}$ & $\%$ \\
\hline Laki - Laki & 54 & 88.5 \\
\hline Perempuan & 7 & 11.5 \\
\hline Total & 61 & 100 \\
\hline
\end{tabular}

Tabel 1 merupakan tabel hasil pengelompokkan data umur pasien DSD di RSMH pada tahun 2013-2017. Pengelompokkan umur dibagi berdasarkan Elizabeth B. Hurlock. Dari 61 pasien, jumlah pasien paling banyak berada dalam rentang umur $>6$ tahun $-\leq 12$ tahun (late-childhood) dengan jumlah 22 orang $(36,1 \%)$. Pasien berumur $\leq 1$ bulan (neonates) berjumlah 2 orang $(3,3 \%)$. Pasien berumur $>1$ bulan $-\leq 1$ 
tahun (early-infancy) berjumlah 2 orang $(3,3 \%)$. Pasien berumur $>1$ tahun $-\leq 2$ tahun (late-infancy) berjumlah 3 orang $(4,9 \%)$. Pasien berumur $>2$ tahun $-\leq 6$ tahun (earlychildhood) berjumlah 19 orang $(31,1 \%)$. Pasien berumur $>12$ tahun - $\leq 15$ tahun (prepubertal) berjumlah 6 orang (9,8\%). Pasien berumur $>15$ tahun $-\leq 18$ tahun (adolescenes) berjumlah 2 orang (3,3\%). Pasien berumur $>18$ tahun (adults) berjumlah 5 orang $(8,2 \%)$. Jenis kelamin yang paling banyak ditemukan adalah laki-laki berjumlah 54 orang $(88,5 \%)$ dan perempuan 7 orang $(11,5 \%)$.

Tabel 2. Karakterisitik Umur Ayah dan Ibu Pasien DSD di RSUP Dr. Mohammad Hoesin Palembang $(\mathrm{n}=61)$

\begin{tabular}{lcc}
\hline $\begin{array}{c}\text { Karakteristik Umur Ayah } \\
\text { (Depkes, 2009) }\end{array}$ & n & \% \\
\hline 17-25 tahun (Remaja Akhir) & 1 & 1,6 \\
26-35 tahun (Dewasa Awal) & 23 & 37,7 \\
36-45 tahun (Dewasa Akhir) & 24 & 39,3 \\
46-55 tahun (Lansia Awal) & 13 & 21,3 \\
\hline \multicolumn{1}{c}{ Total } & $\mathbf{6 1}$ & $\mathbf{1 0 0}$ \\
\hline Karakteristik Umur Ibu & $\mathbf{n}$ & $\mathbf{\%}$ \\
(Depkes, 2009) & 2 & 3,3 \\
\hline 17-25 tahun (Remaja Akhir) & 32 & 52,5 \\
26-35 tahun (Dewasa Awal) & 22 & 36,1 \\
36-45 tahun (Dewasa Akhir) & 5 & 8,2 \\
46-55 tahun (Lansia Awal) & $\mathbf{6 1}$ & $\mathbf{1 0 0}$ \\
\hline Total &
\end{tabular}

Data mengenai umur ayah pasien DSD di RSMH pada tahun 2013-2017 disajikan pada tabel 2. Pembagian kelompok umur dibagi berdasarkan kriteria umur menururt Depkes RI 2009. Dari 61 ayah pasien, jumlah paling banyak berada dalam rentang umur 36-45 tahun (dewasa akhir) dengan jumlah 24 orang (39,3\%). Pasien 17-25 tahun (remaja akhir) berjumlah 1 orang $(1,6 \%)$. Pasien berumur 26-35 tahun berjumlah 23 (37,7\%) orang. Pasien berumur 46-55 (lansia awal) tahun berjumlah 13 orang $(21,3 \%)$. Pembagian kelompok umur dibagi berdasarkan kriteria umur menurut Depkes RI 2009. Hasil yang didapatkan dari $61 \mathrm{ibu}$ pasien, jumlah paling banyak berada dalam rentang umur 26-35 tahun (dewasa awal) dengan jumlah 32 orang $(52,5 \%)$. Pasien 17-25 tahun (remaja akhir) berjumlah 2 orang (3,3\%). Pasien berumur 36-45 tahun (dewasa akhir) berjumlah 22 orang $(36,1 \%)$. Pasien berumur 46-55 (lansia awal) tahun berjumlah 5 orang $(8,2 \%)$.

Tabel 3. Karakterisitik Status Ekonomi dan Pendidikan Terakhir Orang Tua Pasien DSD di RSUP Dr. Mohammad Hoesin Palembang $(n=61)$

\begin{tabular}{lll}
\hline Karakteristik Status Ekonomi & n & \% \\
\hline $\begin{array}{l}\text { Golongan kelas atas } \\
\text { (>Rp 3.500.000/bulan) }\end{array}$ & 31 & 50,8 \\
$\begin{array}{l}\text { Golongan kelas menengah } \\
\text { (Rp1.500.000-2.500.000/bulan) }\end{array}$ & 17 & 27,9 \\
$\begin{array}{l}\text { Golongan Kelas Bawah } \\
\text { (<Rp 1.500.000/bulan). }\end{array}$ & 13 & 21,3 \\
\hline Total & $\mathbf{6 1}$ & $\mathbf{1 0 0}$ \\
\hline Karakteristik Pendidikan Ayah & $\mathbf{n}$ & $\mathbf{\%}$ \\
Terakhir & 1 & 1,6 \\
\hline $\begin{array}{l}\text { Sekolah Dasar (SD) } \\
\text { Sekolah Menengah Pertama (SMP) }\end{array}$ & 1 & 1,6 \\
Sekolah Menengah Atas (SMA) & 48 & 78,7 \\
Sarjana & 11 & 18 \\
\hline Total & $\mathbf{6 1}$ & $\mathbf{1 0 0}$ \\
\hline Karakteristik Pendidikan Ibu & $\mathbf{n}$ & $\mathbf{\%}$ \\
Terakhir & 2 & 3,3 \\
\hline Sekolah Dasar (SD) & 2 & 3,3 \\
Sekolah Menengah Pertama (SMP) & 48 & 78,7 \\
Sekolah Menengah Atas (SMA) & 9 & 18 \\
\hline Sarjana & $\mathbf{6 1}$ & $\mathbf{1 0 0}$ \\
\hline Total & & \\
\hline
\end{tabular}

Pada tabel 3 dipaparkan hasil status ekonomi orang tua pasien DSD di RSMH pada tahun 2013-2017. Data ini dikelompokkan berdasarkan kelompok status ekonomi Badan Pusat Statistik 2012. Distribusi status ekonomi orang tua pasien DSD didapatkan dari 61 sampel, jumlah paling banyak berada dalam status ekonomi golongan kelas atas (>Rp 3.500.000/bulan) dengan jumlah $31(50,8 \%)$. Golongan status ekonomi kelas menengah ( $\mathrm{Rp} 1.500 .000-$ 2.500.000/bulan) dengan jumlah 17 
(27,9\%). Kemudian golongan kelas bawah (<Rp 1.500.000) berjumlah 13 (21,3\%).

Distribusi pendidikan terakhir ayah pasien DSD di RSMH pada tahun 2013-2017 disajikan dalam Tabel 3. Dari 61 sampel, jumlah paling banyak adalah pendidikan terakhir SMA dengan jumlah 48 orang $(78,7 \%)$. Kemudian jumlah yang termasuk pendidikan terakhir SD berjumlah 1 orang $(1,6 \%)$. Jumlah ayah pasien dengan pendidikan terakhir SMP berjumlah 1 orang (1,6\%), dan terakhir ayah pasien dengan pendidikan terakhir sarjan berjumlah 11 orang (18\%).

Berdasarkan Pendidikan ibu, dari 61 sampel, jumlah paling banyak adalah pendidikan terakhir SMA dengan jumlah 48 orang $(78,7 \%)$. Kemudian jumlah yang termasuk pendidikan terakhir SD berjumlah 2 orang $(3,3 \%)$. Jumlah ibu pasien dengan pendidikan terakhir SMP berjumlah 2 orang $(3,3 \%)$, dan terakhir ayah pasien dengan pendidikan terakhir sarjana berjumlah 9 orang (18\%).

Tabel 4 merupakan distribusi budaya lokal pasien DSD berdasarkan tempat tinggal pasien DSD di RSMH pada tahun 2013-2017. Pembagian kelompok daerah dibagi berdasarkan pembagian wilayah Sumatra Bagian Selatan. Dari hasil pembagian, paling banyak didapatkan pasien bertempat tingggal di Palembang berjumlah 14 orang (23\%). Kemudian pasien yang bertempat tinggal di Komering Ulu, Bengkulu, Prabumulih, dan Bangka Belitung masing-masing berjumlah 2 orang $(3,3 \%)$. Pasien yang bertempat tinggal di Banyuasin dan Jambi masing-masing berjumlah 3 orang $(4,9 \%)$. Pasien yang bertempat tinggal di Lahat, Ogan Komering Ilir masing-masing berjumlah 4 orang $(6,6 \%)$. Pasien yang bertempat tinggal di Ogan Ilir berjumlah 5 orang $(8,2 \%)$. Pasien yang bertempat tinggal di Musi Banyuasin dan Muara Enim berjumlah 6 orang $(9,8 \%)$.
Pasien yang bertempat tinggal di Komering Ulu Timur berjumlah 7 orang $(11,5 \%)$.

Tabel 4. Karakterisitik Budaya Lokal Pasien DSD berdasarkan Tempat Tinggal di RSUP Dr. Mohammad Hoesin Palembang $(\mathbf{n}=61)$

\begin{tabular}{lll}
\hline Karakteristik Umur & $\mathbf{n}$ & $\mathbf{\%}$ \\
\hline Palembang & $\mathbf{1 4}$ & $\mathbf{2 3}$ \\
Banyuasin & 3 & 4,9 \\
Musi Banyuasin & 6 & 9,8 \\
Lahat & 4 & 6,6 \\
Muara Enim & 6 & 9,8 \\
Ogan Ilir & 5 & 8,2 \\
Ogan Komering Ilir & 4 & 6,6 \\
Komering Ulu & 2 & 3,3 \\
Komering Ulu Timur & 7 & 11,5 \\
Pagar Alam & 1 & 1,6 \\
Prabumulih & 2 & 3,3 \\
Jambi & 3 & 4,9 \\
Bengkulu & 2 & 3,3 \\
Bangka Belitung & 2 & 3,3 \\
\hline Total & $\mathbf{6 1}$ & $\mathbf{1 0 0}$ \\
\hline
\end{tabular}

\section{PEMBAHASAN}

Hasil penelitian di Instalasi Rekam Medik RSUP Dr. Mohammad Hoesin Palembang didaptakkan 61 sampel dengan diagnosis DSD dengan jumlah pasien paling banyak berada dalam rentang umur $>6-\leq 12$ tahun (late-childhood) dengan jumlah 22 orang $(36,1 \%)$ dan jumlah pasien paling sedikit berada di rentang umur $\leq 1$ bulan $-\leq 1$ tahun masing-masing sebanyak 2 pasien $(3,3 \%)$.

Hasil penelitian ini selaras dengan penelitian yang dilakukan di Rumah Sakit Dr. Kariadi Semarang pada tahun 2011 didapatkan 286 pasien terdiagnosis DSD pada tahun 2004-2010, didapatkan 161 pasien yang terdiagnosis DSD berumur $>6$ 11 tahun dan pasien yang terdiagnosis DSD $<6$ tahun berjumlah 85 orang (Ediati et al., 2014).

Penelitian yang dilakukan oleh Juniarto pada tahun 2012 di Semarang, pasien terbanyak berumur $>5-\geq 12$ tahun. Dari 88 pasien yang terdiagnosis, 27 pasien baru 
terdiagnosis saat umur $>5 \quad-\geq 12$ tahun (Juniarto et al., 2012). Hasil yang sama juga didapatkan pada penelitian yang dilakukan di Rumah Sakit Departemen Endokrinologi New Delhi pada tahun 2002 didapatkan pasien DSD yang terdaftar sebanayak 74 pasien, 52 pasien terdaftar saat berumur $>5$ tahun (Ammini et al., 2002).

Persamaan hasil yang didapatkan kemungkinan karena pasien baru menyadari pada saat umur memasuki pubertas tidak terjadi perkembangan seks sekunder yang signifikan (Krausz, 2011). Contohnya pada pasien dengan diagnosis Gonadal Dysgenesis, manifestasi klinis akan terlihat semakin jelas ketika memasuki umur pubertas. Menurut penelitian Ananda pada tahun 2016, sebanyak 50\% pasien Gonadal Dysgenesis memiliki bentuk testis yang normal dan baru terdiagnosis pada saat umur $\geq 11$ tahun (Ananda et al., 2016) Selain itu pasien laki-laki di Indonesia banyak terdiagnosis pada saat umur $>5-\geq 12$ tahun (childhood) karena pada umur tersebut orang tua membawa anaknya ke mantri untuk disunat sehingga baru terlihat adanya kelainan pada organ genitalia eksternal (Rokoyah, 2016).

Hasil penelitian yang dilakukan oleh Shawky pada tahun 2012 di Cairo berbeda dengan penelitian lainnya. Penelitian mengenai umur pasien DSD di Cairo didapatkan pada umur $12-\geq 15$ tahun (Adolesence) paling banyak ditemukan. Dari 908 pasien yang terdiagnosis sebanyak 302 pasien terdiagnosis pada saat umur $12-\geq 15$ tahun. Hal ini disebabkan karena orang tua pasien DSD merasa malu membawa anaknya untuk dilakukan tatalaksana (Shawky et al., 2012). Selain itu alasan pasien baru terdiagnosis ketika memasuki umur anakanak bahkan dewasa diakibatkan oleh kurangnya pengetahuan tentang DSD. Bukan hanya masyarakat umum saja yang kurang pengetahuan tenang DSD bahkan beberapa tenaga ahli medis masih banyak yang sulit untuk menegakkan diagnosis DSD pada saat kelahiran. Menurut penelitian yang dilakukan Ediati pada tahun 2011 di Semarang pasien baru datang pada saat memasuki umur childhood-adolesence dikarenakan adanya stigma dari masyarakat. Akibatnya orang tua takut untuk membawa anaknya kepada tenaga medis karena mereka menganggap kondisi tersebut merupakan "karma" dan tidak bisa disembuhkan (Ediati, 2013). Padahal sudah ada upaya penyembuhan yang dapat dilakukan seperti tindakan operasi dan terapi hormon pasien DSD. Untuk terapi hormon, pada perempuan menggunakan hormon esterogen dan lakilaki hormon testosteron (Gong et al., 2021).

Distribusi jenis kelamin dari hasil penelitian di Instalasi Rekam Medik RSUP Dr. Mohammad Hoesin Palembang didapatkan 7 pasien perempuan $(11,5 \%)$ dan 54 pasien laki-laki $(88,5 \%)$. Hasil berbeda dengan penelitian yang dilakukan di Semarang dari 39 pasien dewasa didapatkan hasil 21 pasien laki-laki $(53,8 \%)$ dan 18 pasien perempuan $(46,2 \%)$ (Ediati, 2014). Hasil penelitian yang dilakukan di India sedikit berbeda, dari 74 pasien diantaranya 29 pasien laki-laki $(39,18 \%), 35$ pasien perempuan $(47,29 \%)$ dan 10 orang jenis kelamin belum terindentifikasi $(13,51 \%) .{ }^{10}$ Menurut penelitian di Bangladesh, rendahnya help seeking behavior pada perempuan dengan permasalahan seksual dikarenakan adanya stigma, peran yang pasif dalam aktivitas seksual, atau karena adanya pengaruh budaya yang kuat; yang sangat umum di negara Asia dengan mayoritas masyarakat muslim. Hal ini karena dianggap sesuatu yang tabu (Acharjee \& Mullick, 2021).

Berbeda dengan hasil penelitian dari Jerman, dimana didapatkan 511 pasien yang menjadi sampel, 144 pasien laki-laki $(28,18 \%)$ dan 367 pasien merupakan pasien 
perempuan (71,81\%) (Lux et al., 2009). Banyaknya pasien perempuan yang datang dikarenakan pasien perempuan lebih banyak mendapatkan stigma dibandingkan laki-laki. Akibatnya banyak pasien yang melakukan pengobatan lebih cepat daripada laki-laki namun dengan keluhan mengalami stress akibat adanya pandangan buruk orang lain terhadap dirinya (Ediati, 2013).

Perbedaan hasil ini diakibatkan di RSMH banyak pasien laki-laki DSD yang terdiagnosis sebagai pasien hipospadia. Angka kejadian hipospadia di Indonesia masih tergolong cukup tinggi. Angka insiden hipospadia berkisar 1:250 kelahiran bayi (Krisna, 2017). Selain itu, salah satu faktor risiko dari hipospadia adalah terpaparnya pestisida pada saat kehamilan. Penelitian yang dilakukan oleh Brouwers pada tahun 2006 di Belanda, sebanyak 30 orang tua $(n=583)$ terpapar oleh pestisida saat kehamilan (Brouwers, 2006). Menurut Badan Pusat Statistik pada tahun 2013 tercatat 58\% penduduk Sumatra Selatan tercatat sebagai pekerja tani (BPS, 2013). Hal ini lah salah satu alasan banyaknya pasien hipospadia di RSMH.

Distribusi umur ayah pasien DSD jumlah paling banyak berada dalam rentang umur 3645 tahun (dewasa akhir) dengan jumlah 24 orang $(39,3 \%)$. Sedangkan untuk umur ibu pasien jumlah paling banyak berada dalam rentang umur 26-35 tahun (dewasa awal) dengan jumlah 32 orang $(52,5 \%)$. Sedangkan untuk umur 17-25 tahun hanya didapatkan 1 ayah pasien $(1,6 \%)$ dan 2 ibu pasien $(3,3 \%)$.

Hasil ini selaras dengan penelitian tentang Health Seeking Behavior di Amerika Serikat karakteristik umur paling banyak pada rentang umur 40-59 tahun $(47,4 \%)$. Kemudian diikuti oleh umur 20-39 tahun (28,7\%), umur 60-97 tahun $(19,4 \%)$ dan paling rendah pada umur $\leq 19$ tahun (Ybbara, 2006). Penelitian tentang Health Seeking Behavior juga pernah dilakukan di Karachi pada tahun 2008 dan didapatkan rata-rata umur pasien yang datang berobat ke dokter untuk mencari pertolongan saat berumur 38 tahun (Siddiqui, 2008). Hasil penelitian Health Seeking Behavior di Indonesia tidak jauh berbeda, sebanyak 112 sampel mencari pertolongan saat umur 23-42 tahun $(81,2 \%)$ dan diikuti 26 sampel mencari pertolongan pada saat umur 43-62 tahun (18,8\%). Hal ini disebabkan karena pada umur produktif ketika menderita suatu penyakit akan lebih cepat menyadari karena hal tersebut dapat menghambat pekerjaan sehari-hari (Lumban, 2013).

Selain itu pada umur dewasa menururt Hurlock (1980) adalah umur psikologi seseorang akan muncul emotional stability, sense of reality, dan sense of resposibility. Pada umur inilah development task seseorang menjadi sangat berkembang contohnya pengalaman hidup semakin bertambah, bertanggung jawab terhadap keluarga, dan merasa harus mampu mendidik dan merawat anak (Hurlock, 1980). Hal inilah menjadi salah satu alasan pasien DSD dibawa pada saat umur orang tua memasuki umur dewasa.

Distribusi status ekonomi orang tua pasien DSD paling banyak berada dalam status ekonomi golongan kelas atas $(>\mathrm{Rp}$ 3.500.000/bulan) dengan jumlah 31 $(50,8 \%)$. Golongan status ekonomi kelas menengah (Rp 1.500.000-2.500.000/bulan) dengan jumlah 17 (27,9\%). Kemudian golongan kelas bawah $(<\mathrm{Rp} 1.500 .000)$ berjumlah 13 (21,3\%).

Hal ini selaras dengan penelitian yang dilakukan Amin di Bangladesh, untuk golongan atas sebesar 54,8 \% untuk golongan kelas menengah $35,7 \%$ dan untuk golongan kelas bawah sebesar 9,5\% (Amin, 2010). Namun hasil penelitian yang dilakukan oleh Lumban di Indonesia pada tahun 2013 sedikit berbeda yaitu, dari 138 sampel didapatkan golongan status ekonomi 
baik sebanyak 57 orang (41,4\%), golongan status ekonomi sedang sebanyak 79 orang $(57,2 \%)$ dan golongan status ekonomi kurang berjumlah 2 orang (1,4\%) (Lumban, 2013). Untuk status ekonomi pada penelitian yang dilakukan oleh Widayati tidak menunjukan hasil yang spesifik untuk golongan bawah didapatkan sebesar $47 \%$, golongan menengah sebesar 32\%, golongan atas sebesar $12 \%$ dan yang tidak menyebutkan pendapatan sebesar 9\% (Widayati, 2012).

Perbedaan hasil penelitian ini bisa disebabkan karena ada perbedaan tingkat pendapatan dari masing-masing daerah yang diteliti (Lumban, 2013). Pada penelitian ini didapatkan hasil pasien yang datang berobat lebih banyak berasal dari golongan atas. Dari 5 pasien didapatkan 4 pasien mempertimbangkan keuangan menjadi salah satu faktor seseorang berani untuk datang ke fasilitas kesehatan (Chausairi, 2004).

Distribusi pendidikan terakhir orang tua pasien DSD paling banyak adalah berpendidikan terakhir SMA dengan jumlah 48 orang $(78,7 \%)$. Hasil ini serupa dengan penelitian yang dilakukan oleh Widayati dengan jumlah 37\% tamat SMA, 29\% tamat sebagai lulusan sarjana, $12 \%$ tamat SMP, 9\% tamat SD dan $13 \%$ tidak menyebutkan pendidikan terakhir (Widayati, 2012). Begitupun dengan penelitian yang dilakukan oleh Lumban pada tahun 2013 pendidikan terakhir paling banyak adalah tamat SMA sebanyak 37\% (Lumban, 2013). Selain itu penelitian tentang karakteristik demografi DSD yang pernah dilakukan di Semarang menyebutkan pendidikan terakhir dari ayah pasien DSD adalah tamat SMA 42,2\% dan ibu dari pasien DSD juga memiliki pendidikan terakhir SMA sebanyak $41,4 \%$ (Ediati, 2014). Ketika tingkat pendidikan seseorang tinggi maka ia memiliki pengetahuan yang baik tentang kesehatan serta mempunyai sikap yang positif tentang usaha mencari pertolongan kesehatan, yaitu dengan cara mendatangi tempat pelayanan kesehatan seperti puskesmas, rumah sakit atau praktek dokter (Lumban, 2013). Tingkat pendidikan yang masih rendah serta kurangnya informasi kesehatan dapat menyebabkan seseorang kurang menyadari arti dari konsep sehat dan sakit. Hal ini yang menyebabkan seseorang mengalami late diagnose (Chausairi, 2004) Selain itu, Health Seeking Behavior ditentukan oleh perilaku dari masing-masing Individu. Sebagai contoh, sebuah penelitian yang dilakukan di Taiwan mengungkapkan wanita dengan umur dewasa akhir dan memiliki pendidikan yang tinggi lebih memilih untuk melakukan pengobatan selfcare daripada harus berobat pada tenaga medis (Widayati, 2012).

Distribusi budaya lokal pasien DSD berdasarkan tempat tinggal pasien DSD paling banyak didapatkan bertempat tingggal di Palembang berjumlah 14 orang (23\%). Tempat tinggal seseorang sangat berpengaruh terhadap perilaku Health Seeking Behavior. Menurut Purnamaningrum di Indonesia terutama di kalangan masyarakat pedesaan perilaku mencari kesehatan masih rendah, banyak yang masih beranggapan semua penyakit akan terselesaikan dengan self-care ataupun berobat kepada mantra (Purnamaningrum, 2010). Jika dilihat dari tenaga kesehatan, banyak daerah pedesaan yang kekurangan tenaga kesehatan karena adanya misdistribusi tenaga kesehatan terutama di negara dengan pendapatan rendah hingga sedang, termasuk Indonesia (Gazali et al., 2019). Selain tenaga kesehatan juga jarak tempat tinggal pasien dengan fasilitas pelayanan kesehatan memiliki pengaruh terhadap Health Seeking Behavior seseorang (Chausairi, 2004). Pada penelitian ini beberapa pasien mengatakan alasan mereka melakukan intervensi di RSMH dikarenakan adanya rujukan akibat fasilitas kesehatan 
didaerah mereka belum memadai. Selain pengetahuan dan keuangan, tersedianyan fasilitas kesehatan menjadi salah satu fakor yang memengaruhi Health Seeking Behavior seseorang (Chausairi, 2004).

Namun menurut penelitian yang dilakukan Ediati tahun 2011 banyak pasien DSD yang datang berobat berasal dari pedesaan. Pada penelitian tersebut didapatkan pasien berasal dari rural sebanyak 45 (55.6\%), suburban 24 (29.6\%), dan urban 12 (14.8\%). Hal ini disebabkan karena mereka pasien yang berasal dari pedasaan lebih banyak mendapatkan stigma dibanding pasien yang berasal dari perkotaan. Sehingga mereka akan datang kepada tenaga kesehatan untuk segera mendapatkan pertolongan (Ediati, 2013). Selaras dengan penelitian health seeking behavior yang dilakukan pada masyarakat urban di Yogyakarta oleh Widayati tahun 2012 yaitu pasien dari golongan urban lebih banyak yang melakukan self-care (penyembuhan dengan cara berisitirahat dan penyembuhan tanpa obat) kemudian diikuti dengan pilihan kombinasi self-care dan mencari pertolongan kepada tenaga kesehatan (Widayati, 2012).

Penemuan pada studi di Bangladesh menetapkan bahwa teman dan orang dekat (sumber informal) memainkan peran besar dalam help seeking (pencarian bantuan) untuk masalah kesehatan seksual. Hal ini dikarenakan mereka memainkan peran utama dalam pemberian saran dan pengambilan keputusan. Tujuannya agar tidak ada ketakutan akan komplikasi di masa depan (Acharjee \& Mullick, 2021). Peranan sumber informal tersebut juga kemungkinan dikarenakan akses untuk menemuinya lebih mudah dibandingkan sumber formal seperti tenaga profesional (Gebreegziabher et al., 2019). Di sini, kesadaran akan masalah seksual mungkin menjadi perhatian besar dalam mencari bantuan dari pengaturan klinis. Temuan ini sangat penting dari sudut pandang klinis saat memberikan atau merencanakan layanan. Selain itu, juga untuk meningkatkan kesadaran akan pentingnya masalah seksual di kalangan masyarakat umum karena mereka memainkan peran utama dalam pengambilan keputusan (Acharjee \& Mullick, 2021).

\section{KESIMPULAN}

Berdasarkan penelitian yang telah dilakukan mengenai karakteristik faktorfaktor Health Seeking Behavior pada pasien Disorder of Sex Development (DSD) di RSUP Dr. Mohammad Hoesin Palembang pada tahun 2013-2017, didapatkan simpulan bahwa pasien DSD di RSUP Dr. Mohammad Hoesin Palembang masih banyak tergolong late diagnose ditinjau dari beberapa faktor Health Seeking Behavior.

\section{UCAPAN TERIMAKASIH}

Penulis mengucapkan terimakasih kepada responden dan pihak RSUP Dr. Mohammad Hoesin Palembang, dosen pembimbing, serta staf Bagian Ilmu Kesehatan Masyarakat Ilmu Kedokteran Komunitas Fakultas Kedokteran Universitas Sriwijaya, Palembang.

\section{DAFTAR PUSTAKA}

Amin, R. (2010) 'Socioeconomic Factors Differentiating Maternal and Child Health Seeking Behavior in Rural Bangladesh: a Cross-sectional Analysis', International Journal for Equity in Health [internet]. [diakses 10 agustus 2018], Tersedia pada: https://equityhealthj.biomedcentral.co m/articles/10.1186/1475-9276-9-9.

Ammini, A. C., Gupta, R., et al. (2002) 'Etiology, Clinical Profile, Gender Identitiy and Long-Term Follow Up of Patients with Ambigous Genitalia in 
India', Journal of Paediatric Endocrinology and Metabolism, India: India Institute of Medical Science New Delhi.

Ananda, C., Prima., M. H., Faradz, et al. (2016) 'Kelainan Fenotip pada Gonadal Dysgenesis 46, XY', Jurnal Kedokteran Universitas Diponegoro.

Acharjee, P. and Mullick, M. S. I. (2021) 'The Pattern of Help-Seeking Behavior Among Patients With Sexual Dysfunctions Attending in Psychiatry Outpatient Department in a Tertiary Care Hospital of Bangladesh', Sex Med, no. 9 , pp. 1-11.

Berglund, A., et al. (2016) 'Incidence, Prevalence, Diagnostic delay, and Clinical Presentation of Female 46, XY Disorder of Sex Development', Journal of Endocrine.

BPS (2013) 'Tenaga Kerja', [internet]. [diakses 17 Desember 2018. Tersedia pada

https://sumsel.bps.go.id/subject/6/tenag a-kerja.html.

Brouwers, M. M., Feitz, W. F. J., Roelofs, L., Kiemeney, L., et al. (2006) 'Risk Factors of Hypospadia', Journal of Pediatrics Netherland.

Chusairi, A. (2004) 'Health Seeking Behavior Para Pasien Poli Perawatan Paliatif Studi Eksploratif terhadap Lima Pasien Poli Perawatan Paliatif RSUD dr. Soetomo Surabaya'. Artikel Psikologi Universitas Airlangga.

Ediati, A., Faradz, S. M. H., et al. (2014) 'Emotional and Behavioral Problem in Late-Identified Indonesian Patients with Disorder of Sex Ddevelopment', Journal of Psychosomatic Research, Faculty of Medicine Diponegoro University.

Ediati, A., Juniarto, A. Z., et al. (2013) 'Body Image and Sexuallity Adults with Disorder of Sex Development' Journal of Sex Reserch, Faculty of Diponegoro University.

Garcia-Acero, M, Moreno-Nino, O., SuarezObando, F., et al. (2020) 'Disorders of sex development: Genetic characterization of a patient cohort', Molecular Medicine REPORTS 21, pp. 97-106.

Gazali, K. M., Syakurah, R. A., \& Fadilah, M. (2019) 'Medical students' interests on rural practices', International Journal of Public Health Science (IJPHS), no. 2, vol. 8, pp. 192-196.

Gebreegziabher, Y., Girma, E., Tesfaye, M. (2019) 'Help-seeking behavior of Jimma university students with common mental disorders: A crosssectional study', PLoS ONE, no. 14, vol. 2, pp. 1-18.

Gong, X. L., Raile, K., SlowikowskaHilczer, J., Pienkowski, C., Quinkler, M., Roehle, R., Nordenström, A., and Neumann, U. (2021) 'Physical and Reported Subjective Health Status in 222 Individuals with XY Disorder of Sex Development', Journal of the Endocrine Society, no. 8, vol. 5, pp. 114.

Hughes, I. (2008) 'Disorder of Sex Development: a New Definition and Classification', Journal of Paediatrics Endocrinoly and Metabolism.

Hurlock, E. B. (1980) 'Psikologi Perkembangan: Suatu Pendekatan Sepanjang Rentang Kehidupan', Jakarta: Gramedia.

Juniarto, A. Z., et al. (2012) 'Application of the New Classification on Patient with a Disorder of Ssex Development in Indonesia', International Journal of Endocrinology, Faculty of Medicine Diponegoro University.

Krausz, C. (2011) 'Male Infertility: Pathogenesis and Clinical Diagnosis', 
Journal of Clinical Physiopathology, Italy.

Krisna, D. M. and Maulana, A. (2017) 'Karakteristik Hipospadia di Indonesia', Jurnal Urologi, Universitas Kristen Duta Wacana.

Lee, P. A., Houk, C. P., Ahmed, S. F., et al. (2006) 'International Consensus Conference on Intersex organised by the Lawson Wilkins Pediatric Endocrine Society and the European Society for Paediatric Endocrinology', Pediatrics, no. 118, pp. e488-e500.

Lumban, T. (2013) 'Pengaruh Faktor Sosiodemografi, Sosioekonomi dan Kebutuhan Terhadap Perilaku Masyarakat Dalam Pencarian Pengobatan di Kecamatan Medan Kota Tahun 2013' Universitas Sumatra Utara.

Lux, A., Kropf, S., et al. (2009) 'Clinical Evaluation Study of the German Networks of Disorder of Sex Development (DSD)/ Intersexuality: study design, description of study population and data quality', Journal of Medicine, Germany: Otto-VonGuericke University.

Purnamaningrum, A. (2010) 'Faktor-faktor yang Berhubungan dengan Perilaku Masyarakat untuk Mendapatkan Pelayanan Kesehatan Mata', Universitas Diponegoro.

Purwanti, A. (2016) 'Disorder of Sex Development: Problem yang dihadapi di Indonesia', Medica Hospitalia, no. 4, vol. 1.

Rokoyah, S. (2016) 'Profil pasien Disorders of Sex Development (DSD) di RSUP Dr. Mohammad Hoesin Palembang', Palembang: Universitas Sriwijaya.

Shawky, R. M. and Nour, E. S. (2012) 'Profile of Disorder of Sexual Differentiattion in the Northeast region of Cairo, Egypt',
Journal of Medical Human Genetics', Egypt University.

Siddiqui, M. S. (2008) 'Health Seeking Behavior of the People: Knowledge, Attitude, and Practices Study of the People of Urban Slum Areas of Karachi', Journal of Physiology Medical, Karachi.

Suorsa, K. (2015) 'Characterizing Early Psychosocial Functioning of Parents of Children with Moderate to Severe Genital Ambiguity due to a Disorder of Sex Development', Journal of Urology.

Widayati, A. (2012) 'Health Seeking Behavior di Kalangan Masyarakat Urban di Kota Yogyakart', Jurnal Farmasi dan Komunitas.

Ybarra, M. L. (2006) 'Help Seeking Behavior and the Internet:a National Survey', Journal of Medical Informatics. 